\title{
Marek Blaszczyk
}

(Gniezno)

\section{ANTROPOLOGIA WOLNOŚCI W FILOZOFII SARTRE'A I LÉVINASA}

\begin{abstract}
This paper sets out to outline the singular nature of the dimension of anthropology of freedom in the philosophies of Jean-Paul Sartre and Emmanuel Lévinas, the leading existentialists of the $20^{\text {th }}$ century. It seems that the phenomenon of human freedom, one of the fundamental issues in philosophical anthropology, in particular in the humanist reflection, proves to be problematic when one seeks to elucidate it without ambiguity. This becomes even more difficult given that it prompts further momentous intellectual quandaries, mostly those concerned with the nature of the meaning of existence itself. The concepts advanced by Sartre and Lévinas - although they represent different visions of the human - undoubtedly provide much philosophical inspiration for all kinds of reflection on the vital issue of freedom.
\end{abstract}

\section{Key words}

human, freedom, responsibility 
Problem wolności człowieka już chyba zawsze pozostanie jednym z rudymentarnych zagadnień filozoficznego namysłu. O jego doniosłości świadczą choćby - projektowane przez myślicieli na przestrzeni lat - rozliczne próby ukonstytuowania owego fenomenu w perspektywie metaantropologicznej. Szczególnie istotne zdaje się tu również to, że refleksja nad kwestią ludzkiej wolności nie ogranicza się li tylko do wyznaczenia ontologicznego usytuowania wewnątrzświatowego, lecz implikuje także cały szereg problematycznych - na wskroś fundamentalnych z punktu widzenia człowieka - pytań o kształt i wymiar poszczególnego jestestwa - przede wszystkim zaś rodzi pytanie o sens samej egzystencji, o swoiste napięcie między zniewoleniem a wolnością właśnie ${ }^{1}$.

Antropologia wolności proponowana przez Jeana-Paula Sartre’a i Emmanuela Lévinasa zdaje się bez reszty wpisywać $\mathrm{w}$ perspektywę egzystencjalistyczną. I choć idee kreślone przez obu filozofów wyraźnie jawią się jako antagonistyczne, sam ich rdzeń pozostaje jednakże podobny, wynika bowiem z głębokiego przejęcia i uświadomienia sobie znaczenia jednostkowego bycia-w-świecie oraz wszelkich reperkusji z tym związanych.

\section{JEAN-PAUL SARTRE I IDEA WOLNOŚCI ABSOLUTNEJ}

Jean-Paul Sartre (1905-1980), wybitny kontynuator myśli Dostojewskiego, uchodzi za czołowego (jeśli nie jedynego) egzystencjalistę francuskiego; zdaje się również filozofem, który problemem ludzkiej wolności parał się niemal całe życie. Leitmotivem twórczości Sartre’a stało się tedy zagadnienie jednostkowego wyboru pryncypiów i wartości, konstytuujących byt i istnienie, atoli wyboru wolnego, wyzutego z esencjalistycznych karbów aprioryzmu. Jako że wolność jako taka stanowi tu wartość samą w sobie, wartość najwyższą („nie możemy wybrać wolności lub jej nie wybrać; jesteśmy po prostu wolni siłą faktu"2), projekt Sartre’owskiego egzystencjalizmu jest optymistyczny - życie człowieka odeń li tylko zależy, przypadłości istnieniowe bytu ludzkiego ostatecznie jawią się jako istotowe konsekwencje wolnego wyboru indywiduum. W tym kontekście postulat wolności absolutnej zdaje się jedynym fenomenem odsłaniającym egzystencjalny sens w ogóle.

${ }^{1}$ Jakkolwiek namysł nad problemem wolności ludzkiej egzystencji swoiście przybiera na silne w refleksji filozoficznej XIX i XX w. Szczególnie wyróżnić tu należy rozważania Hegla, Kierkegaarda, Dostojewskiego czy Nietzschego, a także Heideggera, Jaspersa, Bierdiajewa czy Camusa.

${ }^{2}$ F. Copleston, Historia filozofii, 9, Warszawa 2006, s. 309. Szerzej zob. ibidem, s. 295-317. Por. M. Warnock, Egzystencjalizm, Warszawa 2006, s. 110-131. 
Wykładnię Sartre’owskiej koncepcji egzystencjalnej wolności odnajdujemy w kluczowym dziele noblisty „Egzystencjalizm jest humanizmem”:

Dostojewski napisał: „gdyby Bóg nie istniał, wszystko byłoby dozwolone”. To właśnie jest punktem wyjścia dla egzystencjalistów. W rzeczy samej, wszystko jest dozwolone, jeżeli Bóg nie istnieje, i w konsekwencji człowiek jest osamotniony, gdyż nie znajduje ani w sobie, ani poza sobą punktu oparcia. Przede wszystkim zaś nie znajduje usprawiedliwienia. Jeżeli rzeczywiście egzystencja poprzedza istotę, nigdy nie będzie można się usprawiedliwić powoływaniem się na naturę ludzką. Inaczej mówiąc, nie istnieje determinizm, człowiek jest wolny, człowiek jest wolnością. Z drugiej strony, jeżeli Bóg nie istnieje, nie widzimy przed sobą wartości czy nakazów, które usprawiedliwiałyby nasze postępowanie. Tak więc nie mamy, ani poza sobą, ani przed sobą w dziedzinie wyższych wartości potwierdzenia czy usprawiedliwienia. Jesteśmy sami, nikt nas nie usprawiedliwi. To chcialbym wyrazić mówiąc, że człowiek skazany jest na wolność. Skazany, ponieważ nie jest stworzony przez siebie samego, a pomimo to wolny, ponieważ raz rzucony w świat, jest odpowiedzialny za wszystko, co robi ${ }^{3}$.

Warto zaznaczyć, że Sartre’a projekt absolutnej wolności zdaje się zasadzać na recepcji Nietzscheańskiej filozofii życia (z hasłem „Bóg umarł” na czele) oraz ogniskować wokół Dostojewskiego medytacji nad kondycją ludzką i ich psychologicznych reperkusji.

Jednostka ludzka, przekonuje Jean-Paul Sartre, jako jedyny byt w przyrodzie - i tu także akcentuje się wymiar człowieczej wolności - w każdym momencie istnienia wykazuje możność neantyzacji otaczającego świata i samej siebie:

samotworzenie się świadomości jest zarazem nieustannym negowaniem: jednostka zdobywa świadomość siebie negując swą tożsamość z bytem zewnętrznym i z innymi ludźmi, a określając się przez przyszłość neguje też swoją tożsamość z przeszłością - swym charakterem, nawykami, skłonnościami. Sens swej przeszłości jednostka tworzy wolnym wyborem sposobu swojego istnienia. Człowiek jest jedynym bytem, w którym egzystencja poprzedza esencję $e^{4}$.

${ }^{3}$ J.P. Sartre, Egzystencjalizm jest humanizmem, [w:] Problem bytu i nicości. Egzystencjalizm jest humanizmem, Warszawa 2001. Cyt. Za: Antologia tekstów filozoficznych, red. M. Bardel, Kraków 2003, s. 112-113. Por. L. Kołakowski, Filozofia egzystencji i porażka egzystencji, [w:] idem, K. Pomian, Filozofia egzystencjalna, Warszawa 1965, s. 26; J. Kossak, Egzystencjalizm w filozofii i literaturze, Warszawa 1976, s. 44-45; W. Tatarkiewicz, Historia filozofii, 3, Warszawa 2005, s. 396-402; W. Granat, Personalizm chrześcijański, Poznań 1985, s. 359-368.

${ }^{4}$ W. Gromczyński, Egzystencjalizm Jeana Paula Sartre’a, [w:] Z. Kuderowicz (red.), Filozofia XX wieku, 1, Warszawa 2002, s. 209. Por. F. Copleston, Historia filozofii, 11, Warszawa 2007, s. 134-141. 
W tej perspektywie wolność jednostki jawi się jako przekraczanie swoiście ludzkich ograniczeń bytu, jako nieustanne projektowanie przyszłych i poprzyszłych możliwości egzystencjalnych.

Jean-Paul Sartre, medytując nad swoistością bytu-w-sobie (en-soI) i bytu-dla-siebie (pour-soi), możnością mediatyzacji owych niesprowadzalnych do siebie rodzajów bytu ${ }^{5}$ zdaje się wyprowadzać również trzeci jego modus byt-dla-innych - że człowiek zrazu, z faktu samego egzystowania, ontycznie sytuuje się w przestrzeni wspól-jestestwa (Heideggerowskie Mitdasein), w relacji do innych jednostek. Świadomość (pre-refleksyjna) i wiedza o innych stanowi tedy, zdaniem francuskiego filozofa, część wiedzy o sobie samym, co może uchodzić za problematyczne z punktu widzenia potencjalnego przekroczenia, neantyzacji, owej wiedzy czy świadomości, otaczającego świata czy - w perspektywie permanentnego dookreślania esencji własnej egzystencji - siebie samego wreszcie. Uprzedmiotowienie wszelkiej inności (dążność do masywności bytu-w-sobie, podkreślmy w duchu personalistycznym, implikuje ontologiczną samotność czy pustkę, ejdetyczną bezdomność istnieniową) zdaje się eo ipso radykalną konsekwencją wynikającą z bezgranicznej, absolutnej wolności bytu-dla-siebie. Jak pointuje Mary Warnock:

inni ludzie bowiem - $\mathrm{z}$ racji samego swego istnienia - stanowią dla nas zagrożenie. W pewnym momencie zdaję sobie sprawę z tego, że stałem się przedmiotem obserwacji Innego, tym samym uprzytamniam sobie, iż będzie on miał własne kryteria oceniania mnie i przewidywania mego zachowania. W rewanżu również ja próbuję zredukować go do rzeczy. Wiem wszakże od samego początku, że nie uda mi się to w pełni'.

Możemy zaiste powiedzieć, że - podług Sartre’a - spojrzenie Innego stanowi źródło lęku, egzystencjalnego niepokoju, ostatecznie przekreśla sensowność antycypacji formowania o nim sądów czy projektowania jego wewnątrzświatowego ukonstytuowania, burząc przeto uniwersum bytu, który go postrzega, dla którego chwilowo, hic et nunc stał się przedmiotem obserwacji i namysłu?

${ }^{5}$ Zob. B. Andrzejewski, M. Moryń, A. Przyłębski, Mały leksykon filozofów, Poznań 1994, s. 105.

${ }^{6} \mathrm{M}$. Warnock Egzystencjalizm, s. 135. „Fakt [istnienia] Innego - pisze filozof - jest bezsporny i porusza mnie do głębi. Uświadamiam go sobie poprzez niepokój; z jego powodu czuję się nieustannie zagrożony. (...) Podczas gdy usiłuję wyzwolić się spod wpływu Innego, Inny próbuje uwolnić się ode mnie; kiedy ja staram się zniewolić Innego, Inny stara się zniewolić mnie". Ibidem, s. 136. O Sartre’owskim projekcie radykalnej wolności zob. także L. Stevenson, D.L. Haberman, Dziesięć koncepcji natury ludzkiej, Wrocław 2001, s. 199-219.

${ }^{7}$ Por. J.P. Sartre, Byt i nicość. Zarys ontologii fenomenologicznej, Kraków 2007, s. 307. 
Jako że człowiek, wedle autora „Mdłości”, jest skazany na wolność, wszelka zmiana przypadłości własnej ontycznej sytuacji w bycie, a więc ustawiczne wybieganie, rzutowanie siebie w nie-zaistniałą jeszcze przyszłość - dopełnione świadomością przeszywającej zewsząd nicości, niekończących się możliwości samookreślenia (przez akt wolnego wyboru właśnie) - wywołuje w nim - jakeśmy pisali - lęk co do samego egzystowania. Zdaniem Sartre’a nierzadko tedy - jako jednostki - uchylamy się od całkowitej wolności, gdyż perspektywa, gdzie wszystko jest dozwolone, spotencjalizowane, a nic aktu wyboru $\mathrm{w}$ istocie nie warunkuje, po prostu nas przytłacza. Egzystujące indywiduum ucieka tym samym w egzystencję nieautentyczną, przestaje być Sobą (popada w bezosobowe Się), a jej mowa, jakby ujął Heidegger, staje się li tylko czczą gadaniną. Sartre określa to zjawisko mianem wkroczenia człowieka w obszar złej wiary, która jawi się - jego zdaniem - jako wyraźne zaprzeczenie absolutnej wolności, czyli tego, co winno być najcenniejsze dla każdego bytu ludzkiego (,akt złej wiary a na celu ucieczkę od tego, od czego uciec nie można; ucieczkę od tego, czym się jest"»). Zła wiara - pointuje filozof - jest zatem fałszowaniem rzeczywistości, wyrazem usprawiedliwienia się człowieka przed sobą samym, przed dokonanymi czynami i wartościami powziętymi w duchu wolności.

Niech podsumowaniem Jeana-Paula Sartre’a idei absolutnej wolności będą słowa skreślone przez filozofa na kartach trzytomowej powieści „Drogi wolności":

być wolnym, być przyczyną samego siebie, móc powiedzieć: jestem, ponieważ tego chcę; być swoim własnym początkiem. (...) obowiązkiem naszym jest robić to wszystko, czego chcemy, myśleć to, co wydaje nam się dobre, być odpowiedzialnym tylko przed sobą i stale kwestionować to, co się myśli - wszystkich w ogóle. (...) Jeśli zaś idzie o wolność, nie byłoby również właściwe zastanawiać się nad nią, bo wtedy człowiek przestaje być wolnym ${ }^{9}$.

\section{EMMANUEL LÉVINAS I DIALOGICZNY WYMIAR WOLNOŚCI}

Emmanuel Lévinas (1906-1995), polemizując z Sartre’owską koncepcją wolności absolutnej („żyjąc w tym samym mniej więcej czasie - pisał o Lévi-

\footnotetext{
${ }^{8}$ J.P. Sartre, Zła wiara i dialektyka świadomości, [w:] L. Kołakowski, K. Pomian, Filozofia egzystencjalna, s. 345. Por. K. Pomian, Sartre’a metafizyka literatury, [w:] Człowiek pośród rzeczy, Warszawa 1973, s. 231-263.

${ }^{9}$ J.P. Sartre, Drogi wolności, Kraków 2005, s. 43, 112.
} 
nasie i Sartre'rze Józef Tischner - i napotykając te same mniej więcej problemy [przede wszystkim fundamentalne pytanie o wolność - M.B.], proponowali inne rozwiązania: Sartre - ateistyczne, Lévinas - religijne. A przecież mimo tych różnic wyjściowych ich drogi zbliżały się i krzyżowały. Byli od siebie zbyt daleko, by ze sobą polemizować. Zarazem jednak byli zbyt blisko niepokoju naszych czasów, by się do siebie nie zbliżać"10), jak i z trwale zakorzenionym $\mathrm{w}$ tradycji filozoficznej Zachodu egotyzmem, jawi się jako orędownik dialogu oraz obrońca wszelkiej Inności ${ }^{11}$. Podług autora „Trudnej wolności" fundamentalnym zagadnieniem filozoficznym winno być zatem poszukiwanie sensu egzystencji (swoista archeologia sensu) oparte na pryncypiach dialogicznych, filozof zaś - przekonuje Lévinas, kontestując zarazem systemowość (totalność) myślenia i heglowski idealizm ${ }^{12}$ - nie powinien tracić $\mathrm{z}$ oczu istnienia poszczególnego, a w centrum swojej refleksji sytuować człowieka i jego bycie („filozofia zajmuje się więc, zdaniem Lévinasa, problemem relacji zachodzącej między człowiekiem a byciem. Relacja ta wynika z faktu, że podmiot poprzez swoje istnienie znajduje się w jakiś sposób wobec bycia. Podstawowym pytaniem filozoficznym jest zatem zagadnienie, jak się przedstawia owo pierwsze i oryginalne odniesienie między człowiekiem i byciem, między człowiekiem a faktem bycia”"13, „prawdziwy dramat człowieka nie rozgrywa się między nim a światem, lecz znajduje dla siebie scenę w samym człowieku - występuje on między nim i jego własnym byciem"14). W myśl koncepcji Lévinasa ontologiczna wolność Toż-Samego zostaje tedy przekroczona (podporządkowanie sobie Inności zniesione), otwierając horyzonty porozumienia $\mathrm{z}$ rzeczywistością transcendentną, mogącą zaznaczyć się jedynie poza obrębem jednostkowego „ja”. Jak pisze Marek Jędraszewski:

wolność ontologiczna jest przede wszystkim wolnością bytu dla siebie. Jego bycie dla siebie urzeczywistnia się w ten sposób, że będąc w świecie, pragnie być $u$ siebie. Być u siebie znaczy to - zdaniem Levinasa - podporząd-

\footnotetext{
${ }^{10} \mathrm{~J}$. Tischner, Wstęp, [w:] M. Jędraszewski, W poszukiwaniu nowego humanizmu. J.P. Sartre - E. Levinas, Kraków 1994, s. 5.

${ }^{11}$ Zob. E. Lévinas, O Bogu, który nawiedza myśl, Kraków 1994, s. 225-234. Por. J. Tischner, Myślenie według wartości, Kraków 1993, s. 179-193.

${ }^{12}$ Zob. E. Lévinas, Całość i nieskończoność, Warszawa 1998, s. 358-363. „Twarz - pisał Lévinas - nie daje się posiąść, wymyka się mojej władzy. W swej epifanii, w swej ekspresji, dający się jeszcze ujmować byt zmysłowy przeobraża się w byt, kory stawia totalny opór ujmowaniu”. Ibidem, s. 232. Por. S. Sarnowski, Zmierzch absolutu? Z problemów filozofii chrześcijańskiej i egzystencjalistycznej, Warszawa 1974, s. 217.

${ }^{13}$ M. Jędraszewski, Wobec innego: relacje międzypodmiotowe w filozofii Emmanuela Lévinasa, Poznań 1990, s. 23.

${ }^{14}$ Ibidem, s. 26.
} 
kowywać sobie wszelką inność. W dążeniu do powszechnej dominacji nad wszystkim tym co inne przejawia się niezależność hipostazy. Ta niezależność zaś wynika z jej największego pragnienia - pragnienia bycia causa sui - bycia przyczyną samej siebie ${ }^{15}$.

Przekroczenie sobości (owego „u siebie”), wyjście poza egoizm czy ontologiczną samotność, podług filozofa, odsłania tym samym fundamentalną prawdę o człowieku, mianowicie, że jako byt jest on w możności otwarcia się na wartości humanistyczne, inność i transcendencję ${ }^{16}$.

Wolność, co warto podkreślić, w projekcie Emmanuela Lévinasa istotowo sprzęga się z odpowiedzialnością, z koniecznością wzięcia przez człowieka na swoje barki tego, co w swej egzystencji dźwiga Drugi, tego, co swoiście ludzkie. Owa - wynikająca z wolności - odpowiedzialność prowadzi tedy do całkowitego zaangażowania się w sprawy Innego, do zastąpienia go w trudzie jego jestestwa, do bycia jego zakładnikiem. Odpowiedzialność za bliźniego, konstatuje Lévinas, jest

pod każdym względem zdumiewająca, prowadzi bowiem do obowiązku odpowiadania za wolność Innego, do odpowiedzialności za jego własną odpowiedzialność, mimo że wolność, jakiej wymagałoby ewentualne zobowiązanie, lub choćby przyjęcie na siebie narzuconej konieczności, nie może ogarnąć możliwości Innego w żadnym teraźniejszym akcie. Wolność Innego nie może tworzyć struktury z moją wolnością ani wchodzić z nią w związek syntetyczny. Odpowiedzialność za bliźniego jest właśnie tym, co wykracza poza legalność i co zobowiązuje poza wszelką umową, a więc tym, co przychodzi do mnie spoza mojej wolności, spoza teraźniejszości, z czasów niepamiętnych. (...) Ale odpowiedzialność, na którą otwieram się (...) godzi we mnie jak coś całkowicie mojego, bo nikt nie może mnie w niej zastąpić. Wzywając mnie niczym oskarżonego, który nie zdoła odeprzeć oskarżenia, czyni ze mnie - w zobowiązaniu - byt nie dający się zastąpić i jedyny. Jakby wybrany. O tyle właśnie, o ile odwołuje się do mojej odpowiedzialności, zabrania, by ktokolwiek mnie wyręczał. Skoro nikt nie może mnie zastąpić, nie mogę bez uchybienia, czyli bez winy, bez kom-

${ }^{15}$ M. Jędraszewski, Homo: capax Alterius, capax Dei. Emmanuela Levinasa myślenie o człowieku i Bogu, Poznań 1999, s. 91-92. Zob. E. Lévinas, Całość i nieskończoność, s. 82-93; idem, Inaczej niż być lub ponad istotą, Warszawa 2000, s. 207-219.

${ }^{16}$ Zob. B. Skarga, Emmanuel Lévinas - metafizyka jako etyka, [w:] Z Kuderowicz (red.), Filozofia XX wieku, 1, s. 114-145. Jak konstatuje sam Lévinas: „tylko relacja z innym człowiekiem wprowadza wymiar transcendencji i prowadzi do całkowicie innego stosunku niż doświadczenie w zmysłowym sensie terminu, względne i egoistyczne”. E. Lévinas, Całość i nieskończoność, s. 226. Por. T. Gadacz, Sens bycia i etyka według Emmanuela Levinasa, [w:] D. Probucka (red.), Etyka i sens życia, Kraków 2011, s. 21-29; A. Grzegorczyk, Filozofia Nieoczekiwanego. Między fenomenologią a hermeneutyką, Poznań 2002, s. 129-136. 
pleksu, uciec od twarzy bliźniego: zostaję oddany Innemu bez możliwości ucieczki ${ }^{17}$.

\section{$\mathrm{W}$ innym zaś miejscu filozof notuje:}

Nieskończony przychodzi mi na myśl w znaczeniu twarzy. Twarz oznacza Nieskończonego. Nigdy nie pojawia się ona jako temat, lecz w samym znaczeniu etycznym; to znaczy w tym, że im bardziej jestem sprawiedliwy, tym bardziej jestem odpowiedzialny; nigdy nie jest się wolnym od obowiązków wobec drugiego ${ }^{18}$.

Etyczny apel nagiej Twarzy drugiego ${ }^{19}$, podług Lévinasa, wzywa do odpowiedzialności, do bezinteresownego (désintéressement) i nieustającego poświęcania siebie, wychodzenia-poza-siebie. Taka zaangażowana postawa, gotowość do ekspiacji za Innego, stawia człowieka u wrót Transcendencji, w epifanii egzystencjalnego Sensu, którego konstytucję kreśli Wartość Najwyższa.

Inny jako Inny - pisze filozof - nie jest inteligibilną formą, związaną $\mathrm{z}$ innymi formami $\mathrm{w}$ procesie intencjonalnego odsłaniania, lecz twarzą, proletariacką nagością, ubóstwem; Inny jest drugim człowiekiem; wyjście z siebie polega na zbliżaniu się do bliźniego; transcendencja jest bliskością, a bliskość - odpowiedzialnością za Innego, zastąpieniem Innego, ekspiacją za Innego, warunkiem - lub bezwarunkowością - bycia zakładnikiem; odpowiedzialność jako odpowiedź jest wcześniejsza niż słowa; transcendencja jest porozumieniem, które ponad zwykłą wymianą znaków zakłada dar, otwartą dłoń - oto kilka określeń etycznych, oddających sens transcendencji jako człowieczeństwa ${ }^{20}$.

Emmanuela Lévinasa dialogiczny wymiar wolności - podsumujmy - jawi się jako polemiczny nie tylko względem tradycji filozoficznej niemieckiego

${ }^{17}$ E. Lévinas, O Bogu, który nawiedza myśl, s. 134-135. Zob. także idem, Inaczej niż być lub ponad istotą, s. 21-24, 43-48, 84-90.

${ }^{18}$ Idem, Etyka i Nieskończony, Kraków 1991, s. 58.

${ }^{19}$ Por. idem, Trudna wolność, Gdynia 1991, s. 9; idem, Etyka i Nieskończony, s. 49. Szerzej zob. idem, Całość i nieskończoność, s. 218-261. Barbara Skarga następująco ujmuje swoistość Lévinasowskiego fenomenu twarzy: „twarz jest naga. Twarz przemawia, mówi do mnie, napomina. Twarz nie jest też jakąś syntezą obrazów tych innych napotykanych w konkretnych doświadczeniach. Można doświadczać obecności innego człowieka, ale nie dostrzegać twarzy. Twarz budzi myślenie, które jest myśleniem nie o czymś lub o kimś, lecz myśleniem dla, a więc takim, które nie jest wiedzą, lecz poddaniem się, które stawia pod znakiem zapytania mnie samego i budzi we mnie odpowiedzialność. Twarz mnie oskarża i mnie wzywa, wobec niej tracę niewinność i nie mogę pozostać w obojętności”. B. Skarga, Emmanuel Lévinas, s. 130.

${ }^{20}$ E. Lévinas, O Bogu, który nawiedza myśl, s. 61. Por. J. Tischner, Spór o istnienie człowieka, Kraków 1999, s. 172, 246-247; idem, Świat ludzkiej nadziei, Kraków 2000, s. 147; M. Jędraszewski, Wobec innego, s. 136-158. 
idealizmu, ale i wobec wszelkich prób reifikacji podmiotu w ogóle; szczególnie zaś zdaje się dystansować do proponowanej przez Sartre’a idei wolności absolutnej, której nieuniknioną konsekwencją jest podporządkowanie sobie inności, a która - podług autora „Całości i nieskończoności” - przyczynia się li tylko do pogłębienia ontologicznej samotności ludzkiego bytu.

\section{PRÓBA PODSUMOWANIA}

Problem ludzkiej wolności - jako że explicite nierozwiązywalny - nadal pozostaje doniosłym zagadnieniem filozoficznym. Zdaje się, że zaprezentowane tu ujęcia Jeana-Paula Sartre’a i Emmanuela Lévinasa, mieszcząc się w paradygmacie egzystencjalistycznym, manifestują zarazem fundamentalny głos w sprawie ukonstytuowania sensu kondycji ludzkiej. W tym kontekście ów namysł nad problemem antropologii wolności może dać asumpt ponownym dyskusjom nad odwiecznymi kwestiami istnieniowymi.

Próbując określić wspólny mianownik dla powyższych idei, można zdaje się powiedzieć, że koncepcja wolności Sartre’a wyraźnie stoi w opozycji do projektu Lévinasa. Tu przede wszystkim uwypukla się pytanie o granice wolności oraz sam sens egzystowania $\mathrm{w}$ świecie pozbawionym aksjologicznych odniesień. Z tej perspektywy Emmanuel Mounier, stając tu w jednym rzędzie z Lévinasem, konstatuje:

któż ją [wolność - M.B.] odróżni od życiowej samowoli i od woli mocy? Jak ona ma być moja, skoro nie mogę jej odrzucić? W jaki sposób przybierze ona ludzkie oblicze, skoro człowiek ma tylko taką postać, jaką mu nadadzą podjęte przezeń decyzje? Kto wyznaczy granice tego, co nieludzkie, skoro granica między tym, co ludzkie, a tym, co nieludzkie, zależy tylko od mojego postanowienia? ${ }^{21}$.

Problematyczność Sartre’owskiej koncepcji wolności - wolności, dodajmy, która nie napotyka granic, gdyż sama je kreuje i burzy - przejawia się również $w$ tym, że dopuszcza (jeśli nie apoteozuje), a contrario do pryncy-

${ }^{21}$ E. Mounier, Wprowadzenie do egzystencjalizmów, Kraków 1964, s. 68. Stanowisko Mouniera następująco komentuje Tadeusz Płużański: „istnieje wolność - ale sartrowska wolność absolutna jest mitem; wolność pojmowana jedynie jako akt wyboru między dżumą a cholerą jest dowodem ślepoty filozoficznej. W rzeczywistości, jak sądzi Mounier, wolność to afirmacja osoby, afirmacja, którą się przeżywa; nie izoluje ona, lecz łączy. Wolność nie jest bytem osoby, lecz sposobem istnienia pełniejszym niż konieczność, jest to wolność uwarunkowana, a nie absolutna”. T. Płużański, Mounier, Warszawa 1967, s. 26. Szerzej na ten temat zob. ibidem, s. 112-119. Por. E. Mounier, Wolność, [w:] ibidem, s. 223-228. 
piów personalistycznych i dialogiki Lévinasa, możność reifikacji podmiotu, traktowanie współbytującego jestestwa nie jako osoby, partnera dialogu, lecz jako napastnika bez reszty zagrażającego substancjalności i wolności „ja”. Podług autora „Trudnej wolności”, jak wykazano, Inny - objawiający się w epifanii Twarzy jako niepowątpiewalne źródło Prawdy i Sensu - jawi się zaś jako bliźni, jako ktoś, kto nawołuje jednostkę do wyzucia się egotyzmu i sobości - przezwyciężenia ontologicznej samotności bytu-dla-siebie - wzywając do ekspiacji za Drugiego oraz powzięcia zań pełnej odpowiedzialności w wymiarze wewnątrzświatowym. Jak expressis verbis konstatuje Lévinas:

Drugi mnie kwestionuje. Podczas spotkania z nim i jego nagą twarzą budzi się we mnie świadomość moralna. Drugi uświadamia mi moją niedoskonałość. Nie jest to uświadomienie czysto teoretyczne - ja czuję się zawstydzony. Zawstydzenie to wiąże się z poczuciem ekscesywności mojej wolności, która dąży do tego, by nad drugim uzurpować swą moc lub nawet go zabić. W chwili spotkania z Innym moja wolność nie znajduje dla siebie fundamentu, czuje się zakwestionowana i kryje się w poczuciu wstydu. W tym sensie moja wolność staje się wolnością ograniczoną ${ }^{22}$.

Jakkolwiek możemy tedy powiedzieć - niezależnie wszak od tego, jak potraktujemy zaprezentowane tu stanowiska - że owo napięcie między ideą wolności absolutnej (Sartre), a dialogicznym jej wymiarem (Lévinas) wyznacza swoistość egzystencjalistycznych rozważań, na wskroś nośną intelektualnie płaszczyznę filozoficznych eksploracji.

\section{Marek Błaszczyk \\ ANTHROPOLOGY OF FREEDOM IN THE PHILOSOPHIES OF SARTRE AND LÉVINAS}

\section{Summary}

The article discusses the problem of freedom of human existence as envisaged in the philosophies of Jean-Paul Sartre and Emmanuel Lévinas. It is also an attempt to confront opposing visions of the human which these thinkers suggested. According to Sartre, individual freedom is absolute, which means that it can subordinate all that is inner-worldly. In contrast, Lévinas claims that freedom is dialogic and it is constituted through dialogue. Thus, human freedom goes hand in hand with their responsibility for the world and for the Other.

\footnotetext{
${ }^{22}$ M. Jędraszewski, Wobec innego: relacje międzypodmiotowe w filozofii Emmanuela Lévinasa, s. 149. Por. idem, Homo: capax Alterius, capax Dei, s. 94, 161-162. Zob. E. Lévinas, O Bogu, który nawiedza myśl, s. 150; idem, Całość i nieskończoność, s. 363-367.
} 


\section{Bibliografia}

Andrzejewski B., Moryń M., Przyłębski A., Mały leksykon filozofów, Poznań 1994.

Copleston F., Historia filozofii, 9, Warszawa 2006.

Copleston F., Historia filozofii, 11, Warszawa 2007.

Granat W., Personalizm chrześcijański, Poznań 1985.

Gromczyński W., Egzystencjalizm Jeana Paula Sartre'a, [w:] Kuderowicz Z. (red.), Filozofia XX wieku, 1, Warszawa 2002, s. 202-217.

Grzegorczyk A., Filozofia Nieoczekiwanego. Między fenomenologią a hermeneutyką, Poznań 2002.

Jędraszewski M., Homo: capax Alterius, capax Dei. Emmanuela Levinasa myślenie o człowieku i Bogu, Poznań 1999.

Jędraszewski M., W poszukiwaniu nowego humanizmu. J.P. Sartre - E. Levinas, Kraków 1994.

Jędraszewski M., Wobec innego: relacje międzypodmiotowe w filozofii Emmanuela Lévinasa, Poznań 1990.

Kołakowski L., Pomian K., Filozofia egzystencjalna, Warszawa 1965.

Kossak J., Egzystencjalizm w filozofii i literaturze, Warszawa 1976.

Kuderowicz Z. (red.), Filozofia XX wieku, 1, Warszawa 2002.

Lévinas E., Całość i nieskończoność, Warszawa 1998.

Lévinas E., Etyka i Nieskończony, Kraków 1991.

Lévinas E., Inaczej niż być lub ponad istotą, Warszawa 2000.

Lévinas E., O Bogu, który nawiedza myśl, Kraków 1994.

Lévinas E., Trudna wolność, Gdynia 1991.

Mounier E., Wprowadzenie do egzystencjalizmów, Kraków 1964.

Płużański T., Mounier, Warszawa 1967.

Pomian K., Człowiek pośród rzeczy, Warszawa 1973.

Sarnowski S., Zmierzch absolutu? Z problemów filozofii chrześcijańskiej i egzystencjalistycznej, Warszawa 1974.

Sartre J.P., Byt i nicość. Zarys ontologii fenomenologicznej, Kraków 2007.

Sartre J.P., Drogi wolności, Kraków 2005.

Sartre J.P., Egzystencjalizm jest humanizmem, [w:] Problem bytu i nicości. Egzystencjalizm jest humanizmem, Warszawa 2001.

Skarga B., Emmanuel Lévinas - metafizyka jako etyka, [w:] Kuderowicz Z. (red.), Filozofia XX wieku, 1, Warszawa 2002, s. 114-145.

Stevenson L., Haberman D.L., Dziesięć koncepcji natury ludzkiej, Wrocław 2001.

Tatarkiewicz W., Historia filozofii, 3, Warszawa 2005.

Tischner J., Myślenie według wartości, Kraków 1993.

Tischner J., Spór o istnienie człowieka, Kraków 1999.

Tischner J., Świat ludzkiej nadziei, Kraków 2000.

Warnock M., Egzystencjalizm, Warszawa 2006. 